\title{
Abundance and production of ice algae in Resolute Passage, Canadian Arctic
}

\author{
Ralph E. H. Smith*, Jeff Anning, Pierre Clement, Glenn Cota** \\ Department of Fisheries and Oceans, Bedford Institute of Oceanography, Box 1006, Dartmouth, Nova Scotia, Canada B2Y 4A2
}

\begin{abstract}
Abundance and photosynthetic activity of ice algae in Resolute Passage in the Canadian high Arctic were measured in relation to in situ irradiance throughout the main growth season in 1985 and 1986. A simple model was used to calculate in situ production rates and the theoretical maximum (light limited) size of crops and production rates. Both the observed and the maximum possible crop sizes and production rates varied directly with irradiance over the natural range of snow cover, and crops attained the theoretical maximum imposed by self-shading ( 77 to $225 \mathrm{mg} \mathrm{m}^{-2}$ chlorophyll a under thin snow cover) in both years. Calculated in situ production of ice algae under thin snow cover (5 to $23 \mathrm{gC} \mathrm{m}^{-2} \mathrm{yr}^{-1}$ ) could equal or exceed typical values for Arctic plankton. Comparison against observed biomass accumulation in the ice indicated that as much as $65 \%$ of the production could be exported from the ice during the growth season. Where light was artificially increased by maintaining snow-free areas, observed crops were much less than the theoretical maximum despite the abscence of photosynthetic photoinhibition. Crops reported from some other arctic sites were also much less than their corresponding theoretical maxima. Low irradiance often limits ice algal growth, but our results suggest that losses associated with excessive irradiance and with grazing by amphipods at near-shore sites are additional factors determining algal abundance and production
\end{abstract}

\section{INTRODUCTION}

Ice algae are proposed to be important primary producers in polar regions, not only for the absolute magnitude of their production but also for its timing and localization (Cross 1982, Horner 1985, Grossi et al. 1987). Subba Rao \& Platt (1984) reviewed the relatively few production estimates for Arctic ice algae and assigned an average value of $10 \mathrm{gC} \mathrm{m}^{-2} \mathrm{yr}^{-1}$, compared to $27 \mathrm{gC} \mathrm{m}^{-2} \mathrm{yr}^{-1}$ for plankton of Arctic shelf waters. Recent data from the Antarctic indicated rates of $40 \mathrm{gC}$ $\mathrm{m}^{-2} \mathrm{yr}^{-1}$ or more under favorable snow cover (Grossi et al. 1987). The Antarctic results also indicated that much of the ice algal production can be lost to grazers or to the water column during the growth season (Grossi et al. 1987). If general, such export will cause production rates inferred from net biomass accumulation to underestimate total production, but direct measurements of production rate are still few for arctic as well as antarctic ice algae.

The availability of light influences ice algal abun-

- Present address: Biology Department, University of Water10o, Waterloo, Ontario, Canada N2L 3 G1

- Present address: Graduate Program in Ecology, University of Tennessee, Knoxville, Tennessee 37996, USA dance and production in the Arctic, Antarctic and Subarctic (Apollonio 1961, 1965, Gosselin et al. 1985, 1986. Horner 1985, Sullivan et al. 1985, Grossi et al. 1987. Smith et al. 1988). In Hudson Bay, light was found limiting to algal photosynthesis in the first half of the growth season but increased to inhibitory levels in the later season (Gosselin et al. 1985, 1986), while in McMurdo Sound, Antarctica, light was found limiting to algal production throughout the growth season (Grossi et al. 1987). In the Arctic, both positive and negative correlations between algal abundance and light availability have been reported (Apollonio 1961, 1965. Clasby et al. 1976, Horner 1985). The absolute abundance of ice algae varies widely even under similar snow cover and presumably, light avallability: from values of 100 to $300 \mathrm{mg} \mathrm{m}^{-2}$ chlorophyll $a$ in the Arctic and Antarctic respectively (Palmisano et al. 1987 , Smith et al. 1988) to more typical values of $30 \mathrm{mg} \mathrm{m}^{-2}$ or less. The larger crops $\left(300 \mathrm{mg} \mathrm{m}^{2}\right)$ may represent the theoretical, light-limited, maximum (Palmisano \& Sullivan 1985, McConville 1985) but the theoretical maximum has never been explicitly derived for ice algae.

More data on the season-integrated production of arctic ice algae in situ would help to resolve the controlling role of light more clearly, but such data are still difficult to collect and relatively rare. Alternatively, 
production rates in situ can, as for phytoplankton (Platt et al. 1980, Lewis et al. 1985), be calculated from the algal photosynthetic light response measured in samples from the natural community together with estimates of the available light in situ. The available light depends on incident solar radiation and its reflection and attenuation by ice and snow, but also on a selfshading effect that can be very strong in ice algal communities (Palmisano et al. 1987, SooHoo et al. 1987). Even if under-ice irradiance measurements are made, a transmission model must still be used to calculate the light available to the algae, and the photosynthetic rates attained in situ.

Our purpose here is to estimate the production rates of ice algae at our site in the Canadian Arctic, in order to test the hypothesis that production is light-limited and to determine whether total production is likely to greatly exceed the observed accumulation of algal biomass in the ice. Our estimates are based on measurements of light transmission and the photosyntheticlight response of the algae, and therefore entail the development and application of a simple model analogous to those used in similar calculations of phytoplankton production (Lewis et al. 1985). Because Antarctic ice is physically different in important ways, we restrict our detailed analysis to the Arctic at this stage. The model also defines the maximum theoretical standing crops and production rates expected if the populations reach the limits set by self-shading. We wished to test the hypothesis that ice algae at our site and elsewhere in the Arctic can attain the light-limited maxima of crop size and production rate.

\section{Theory}

Light. In the arctic, the ice algae are overwhelmingly concentrated in a thin ( 1 to $4 \mathrm{~cm}$ ) layer at the bottom of an ice sheet that is typically 1.5 to $2.5 \mathrm{~m}$ thick (Horner 1985). The photon fluence rate (PFR) incident at the surface of the ice sheet ( $\left.I^{\prime}\right)$ is partially reflected. A lesser proportion is reflected if the ice surface is free of snow. The light is then attenuated in passage through the ice and snow to a much smaller flux incident upon the algal layer $\left(I_{0}\right)$. The flux is further attenuated in passage through the pigmented algal layer, which is most commonly confined to a narrow band of a few $\mathrm{cm}$ or less at the bottom of the ice sheet in the Arctic, leaving the amount $I_{u}$ penetrating to the water column. To a first approximation, $I_{u}$ can be modelled using the relatively simple relationship

$$
\ln \left(I_{\mathrm{u}} / \mathrm{J}^{\prime}\right)=-\mathrm{a}-\mathrm{c} \cdot \mathrm{X}-\mathrm{k}_{\mathrm{i}} \mathrm{Z}_{1}-\mathrm{k}_{\mathrm{s}} \mathrm{Z}_{\mathrm{s}}-\mathrm{k}_{\text {chl }} \text { [Chl] }
$$

where $\mathrm{a}=$ parameter for reflection from bare ice (dimensionless); $c=$ (dimensionless) parameter for extra reflection from snow $(X=1)$ vs bare ice $(X=0) ; Z_{i}$ and $Z_{\mathrm{s}}=$ ice and snow thickness $(\mathrm{m}) ; \mathrm{k}_{1}$ and $\mathrm{k}_{\mathrm{s}}=$ diffuse attenuation coefficients for ice and snow $\left(\mathrm{m}^{-1}\right)$. All parameters are variable; for example, 'a' varies with sun angle. For this first approximation, we will use constant values for the parameters as estimated by empirical analysis of light transmission data from our study area. [Chl] denotes the areal concentration (mg $\mathrm{m}^{-2}$ ) of chlorophyll $a_{1}$ and $k_{\mathrm{chl}}$ is the mean spectral extinction coefficient for chlorophyll $\left(\mathrm{m}^{2} \mathrm{mg}^{-1}\right)$, more usually denoted $k_{\ddot{c}}$ (Bannister \& Weidemann 1984). We use the term $k_{\text {chl }}$ to emphasize that, as we measure it, the parameter will be influenced by a number of factors other than purely algal light absorption. These factors, and the model's parameter values relative to those from more detailed investigations of light transmission (Warren 1982, Bannister \& Weidemann 1984, Maykut 1985) will be described in the 'Discussion'.

If we assume, as is the case in the arctic sea ice we are considering, that the algal layer lies at the bottom of the ice sheet, then Equation 1 defines PFR at the top of the algal layer, $\mathrm{I}_{0}$ as:

$$
\mathrm{I}_{\mathrm{o}}=\mathrm{I}^{\prime} \quad \exp \left(-\mathrm{a}-\mathrm{c} \quad \mathrm{X}-\mathrm{k}_{\mathrm{i}} \cdot \mathrm{Z}_{\mathrm{l}}-\mathrm{k}_{\mathrm{s}} \mathrm{Z}_{\mathrm{s}}\right)
$$

where $I_{0}=$ maximum PFR that algal cells may experience in situ. The lower PFR actually experienced by cells within the algal layer can be calculated as:

$$
I(B)=I_{0} \cdot \exp \left(-k_{c h i} \quad B\right)
$$

where $I(B)=P F R$ at some point in the algal layer above which the areal concentration of chlorophyll is B (mg $\mathrm{m}^{-2}$ ). B ranges from zero at the top of the algal layer to $[\mathrm{Chl}]$, the vertically-integrated areal concentration defined above, at the bottom. Equation 3 allows us to specify the PFR (ignoring selective spectral attenuation) received by a cell anywhere in the algal layer in terms of the areal concentration of chlorophyll, independent of its precise vertical distribution.

Photosynthesis. We use the following equation (Platt et al. 1980. Lewis et al. 1985) for the biomass-specific photosynthetic rate $\left[P^{B}, \mu g C(\mu g \mathrm{Chla}]^{-1} \mathrm{~h}^{-1}\right)$ as a function of PFR ( $I$, umol quanta $\left.\mathrm{m}^{-2} \mathrm{~s}^{-1}\right)$ :

$$
\mathrm{P}^{B}=\mathrm{P}_{\mathrm{m}}^{\mathrm{B}}\left[1-\exp \left(\mathrm{I} / \mathrm{I}_{\mathrm{K}}\right)\right]
$$

where $\mathrm{P}_{\mathrm{m}}^{\mathrm{B}}=$ light-saturated maximum in $\mathrm{P}^{\mathrm{B}} ; \mathrm{I}_{\mathrm{K}}=$ adaptation parameter $I_{K}$ in turn equals $\mathrm{P}_{\mathrm{m}}{ }^{\mathrm{B}} / \alpha$, where $\alpha$ is the initial slope of the $P^{B}$ vs I curve. Equation 4 fits the photosynthetic light response of ice algae adequately in our experience, so long as I does not greatly exceed values typical of the natural environment. Photoinhibition can occur at higher PFR (Cota 1985).

We assume that respiration rate $\left(\mathrm{R}^{B}, \mu \mathrm{gC}(\mu \mathrm{gChla})^{-1}\right.$ $h^{-1}$ ) is independent of light, and is a constant fraction of $\mathrm{P}_{\mathrm{m}}^{\mathrm{B}}$. This assumption is commonly made in models of microalgal growth (Wofsy 1983). 
The rate of net photosynthesis, $P_{n}$, of the ice algal community ( $\mathrm{mgC} \mathrm{m} \mathrm{m}^{-2} \mathrm{~h}^{-1}$ ) is then given by integrating the quantity $\left(\mathrm{P}^{\mathrm{B}}-\mathrm{R}^{\mathrm{B}}\right)$ from the top of the algal layer to the bottom:

$$
\begin{aligned}
& \mathrm{P}_{\mathrm{n}}=\int_{0}^{[\mathrm{chl}]}\left(\mathrm{P}^{\mathrm{B}}-\mathrm{R}^{\mathrm{B}}\right) \cdot \mathrm{dB} \\
& \left.=\mathrm{P}_{\mathrm{m}}^{\mathrm{B}} \cdot \int_{0}^{[\mathrm{chl}]}\left[1-\exp \left(-\mathrm{I} / \mathrm{I}_{\mathrm{k}}\right)\right]\right] \cdot \mathrm{dB}-\mathrm{R}^{\mathrm{B}} \quad[\mathrm{Chl}]
\end{aligned}
$$

Fig. 1 portrays the functional response of integrated photosynthesis and respiration and their difference $\left(\mathrm{P}_{\mathrm{n}}\right)$

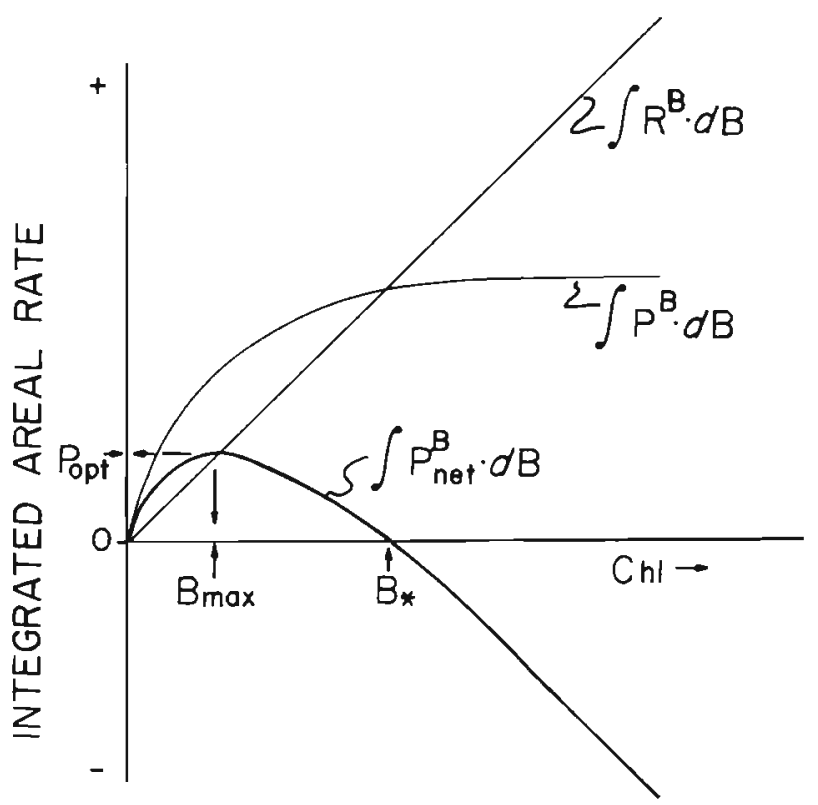

Fig. 1. Functional relation between vertically integrated areal production and respiration rates ( $\left.\mathrm{mgC} \mathrm{m} \mathrm{m}^{-2} \mathrm{~h}^{-1}\right)$ and integrated areal chlorophyll concentration, $\mathrm{Chl}\left(\mathrm{mg} \mathrm{m}^{-2}\right)$. All terms defined in the Introduction (Theory)

to increasing algal crop size, [Chl]. Substituting I(B) from Equation (3) for I in Equation (5) and solving the integral leads to:

$$
\begin{aligned}
& P_{n}=\left(P_{m}^{B} / k_{c h l}\right) \int_{n=1}^{\infty}\left[\left\{(-I \cdot)^{n} \cdot(-1+\exp \right.\right. \\
&\left.\left.\left.\left(-n \cdot k_{c h l}[C h l]\right)\right)\right\} /(n \cdot n !)\right]-R^{B} \cdot[C h l]
\end{aligned}
$$

where $I=$ the quantity $\left(I_{o} / I_{k}\right)$. In calculating production by Equation (6), we ignore variation of PFR through the $24 \mathrm{~h}$ photocycle, and assume instead that we can use a daily average value. This is not entirely accurate even during the period of nominally continuous days (April 23 onwards at Resolute) but is not a serious problem so long as the PFR experienced by the algae is usually close to or less than $I_{k}$.

Upper bounds. Fig. 1 shows that algal net production is at a light-limited maximum (termed $\mathrm{P}_{\mathrm{opt}}$ ) when the rate of increase of integrated photosynthesis with addi- tional standing crop just equals the rate of increase of integrated respiration:

$$
\mathrm{dP}_{\mathrm{n}} / \mathrm{dB}=\mathrm{d}\left[\int_{0}^{[c h]]} \mathrm{P}^{\mathrm{B}} \mathrm{dB}\right] / \mathrm{dB}-\mathrm{d}\left[\int_{0}^{[c h l \mid} \mathrm{R}^{\mathrm{B}} \mathrm{dB}\right] / \mathrm{dB}=0 \text { (7) }
$$

When the equality in Equation 7 holds, the biomassspecific rates of photosynthesis and respiration just balance at the bottom of the algal layer. The PFR at which photosynthesis just balances respiration is termed the light compensation point for photosynthesis, $I_{c}$ and setting Equation 4 equal to $R^{B}$ :

$$
\mathrm{I}_{\mathrm{c}}=\mathrm{I}_{\mathrm{k}} \ln \left(1-\mathrm{R}^{\mathrm{B}} / \mathrm{P}_{\mathrm{m}}^{\mathrm{B}}\right)
$$

The algal standing crop, [Chl], that corresponds to $P_{\text {opt }}$ can then be defined as the crop that reduces $I_{o}$ to $I_{C}$ and Equation 3 can be solved for the condition $I(B)=I_{c}$ to obtain:

$$
\begin{array}{cl}
\mathrm{B}_{\max }=\left(-1 / \mathrm{k}_{\mathrm{chl}}\right) \cdot \ln \left(\mathrm{I}_{\mathrm{o}} / \mathrm{I}_{\mathrm{C}}\right) \\
=\left(-1 / \mathrm{k}_{\mathrm{chl}}\right) \cdot \ln \left[\left(-\mathrm{I}_{\mathrm{k}} / \mathrm{I}_{\mathrm{o}}\right)\right. & \left.\ln \left(1-\mathrm{R}^{\mathrm{B}} / \mathrm{P}_{\mathrm{m}}^{\mathrm{B}}\right)\right]
\end{array}
$$

$P_{\text {opt }}$ is then given by evaluating Equation 6 for the condition $[\mathrm{Chl}]=\mathrm{B}_{\max } \cdot \mathrm{B}_{\max }$ represents an upper limit to crop size as well as to production, inasmuch as any further increase would result in some proportion of the community being held continuously below the light compensation point for photosynthesis. This contrasts with the situation of phytoplankton in a well-mixed water column, for which the upper limit to crop size is reached only when the average PFR in the entire community is reduced to $I_{c}$ (at standing crop B. in Fig. 1 ; cf Sverdrup 1953, Wofsy 1983). In the case of ice algal communities that have attained $\mathrm{B}_{\max }$, populations in the upper algal layer could continue to increase if light alone regulated their growth while those below declined. If so, the algae should as a population penetrate ever upward into the ice. In practice, however, such penetration is severely constrained by the increasingly cold, dense and nutrient-poor nature of the ice algal habitat above a narrow (1 or $2 \mathrm{~cm}$ thick) porous layer adjoining the ice-water interface (the skeletal layer, Maykut 1985). Brine channels provide some exceptions to such a vertical gradient of conditions, but appear to offer much less habitat area than the porous skeletal layer. Observation shows that arctic ice algae normally remain overwhelmingly confined to the narrow bottom layer throughout the growth season (Poulin et al. 1983, Cota et al. 1987, R. Smith, A. Herman unpubl.). We assume that, as crops attain and begin to surpass $B_{\max }$, further growth upward is effectively prevented by stresses other than light limitation in the upper layer. The maximum crop is therefore determined jointly and in a spatially organized way by light and other (not positively identified) factor(s), but should be predictable from the condition that cells at the lower bound of the community experience $I_{C^{\prime}}$ The maximum crop accordingly should be $B_{\max }$ (Equation 9). 


\section{MATERIALS AND METHODS}

Sampling sites and methods. Study sites for 1985 and 1986 were located several $\mathrm{km}$ offshore from Resolute, N.W.T. $\left(74^{\circ} 40^{\prime} \mathrm{N}, 94^{\circ} 54^{\prime} \mathrm{W}\right)$ where the water column is roughly $100 \mathrm{~m}$ in depth. In 1984, routine sampling was carried out closer to shore, where the water column was about $30 \mathrm{~m}$ deep, but additional sampling was carried out along a transect extending several $\mathrm{km}$ offshore. The area is described more fully in Cota et al. (1987). Our period of observation was from late March to late May or early June in each year, spanning the main ice algal growth season.

The sampling program was designed to examine algal growth under 3 or, usually, 4 different depths of snow cover, 18 to 22,8 to 12 , or 2 to $4 \mathrm{~cm}$, and an artificially-cleared area in 1984 and 1985. The cleared areas were established roughly at the outset of the sampling season and at least $3 \mathrm{wk}$ before any samples for photosynthetic measurements were taken. For quantitative assessment of the areal concentration of algal biomass (chlorophyll a) we used a coring auger (SIPRE), cutting off and melting the lower $3 \mathrm{~cm}$ of each core which contained virtually all of the pigment. Aliquots of the melted core section were filtered through $\mathrm{GF} / \mathrm{F}$ filters, the filters were extracted in $90 \%$ acetone, and fluorescence was measured on a fluorometer calibrated against pure chlorophyll a (Smith et al. 1988). An acidification step was included to correct for phaeopigments which were rarely abundant in the ice algae samples. We collected triplicate cores from each of the different snow depths at intervals of 7 to $10 \mathrm{~d}$ through the observation period.

Photosynthesis and respiration measurements. Samples for physiological measurements were obtained by scraping the lower $1.0 \mathrm{~cm}$ or so of the ice (containing most of the visible pigment) into filtered seawater before melting (Bates \& Cota 1986, Smith et al. 1987) at temperatures of -1.0 to $-1.5^{\circ} \mathrm{C}$ in neardarkness. Suspensions so obtained were close to surfaced seawater salinity (ca $30 \mathrm{ppt}$ ) and usually contained 50 to $200 \mathrm{ug} \mathrm{l}^{-1}$ of chlorophyll a. Other salinities (i.e. relative sea water contents) and sample preparation methods yielded only suspensions with lower photosynthetic rates (Bates \& Cota 1986), suggesting that we achieved reasonably favorable conditions for ice algal photosynthetic measurements despite the unavoidable disruption of their natural physical and chemical environment (Smith et al. 1988). Photosynthesis was measured by both change in dissolved oxygen and by ${ }^{14} \mathrm{C}$ assimilation in separate, but usually concurrent, experiments on 6 (oxygen) or $15\left({ }^{14} \mathrm{C}\right.$ ) occasions throughout the observation period in 1985

Experiments for dissolved oxygen change were conducted under fluorescent light filtered through a blue acrylic screen, as previously described (Smith et al. 1987). Four different light levels (plus darkness) were available in the incubator. Dissolved oxygen was determined at the outset and after 6 and $24 \mathrm{~h}$ of incubation. using a high-precision, automated Winkler titration system and $\mathrm{KIO}_{3}$ standards. The samples were incubated in borosilicate glass bottles of 30 or $60 \mathrm{ml}$ volume. Frequent measurements showed that the incubator remained at $-1.0^{\circ} \mathrm{C}$, close to the ambient natural temperature of -1.7 to $-1.8^{\circ} \mathrm{C}$. PFR $(400$ to $700 \mathrm{~nm})$ in the incubator was measured both with a LI-COR Inc. $4 \pi$ quantum probe and with a Biospherical Instruments $4 \pi$ quantum probe, the 2 probes agreeing to within $10 \%$. With change of position in each compartment of the incubator, PFR varied by up to $20 \%$ of its value in the centre of the compartment. For present purposes the imprecise knowledge of PFR in the incubator is not important, since we will mainly be concerned only with the ratio of oxygen production at light saturation to consumption in the dark.

The same incubator was used to measure time courses of photosynthetic ${ }^{14} \mathrm{C}$ assimilation (Smith et al. 1987), which proved to be linear over intervals from one-half up to $24 \mathrm{~h}$ at least. Extracellular release of labelled dissolved organic carbon was also measured, and was found to be in the range of 5 to $15 \%$ of total assimilation for the incubation periods of up to at least $24 \mathrm{~h}$ duration (Smith unpubl.).

Photosynthesis was also measured by ${ }^{14} \mathrm{C}$, using a small-volume, short duration incubation system (Lewis \& Smith 1983, Cota 1985). The incubator provided measurements of the rate of total (dissolved plus particulate) organic fixation over $1 \mathrm{~h}$ of incubation at 24 different irradiances. The estimated production rate should be close to gross photosynthesis because of the short incubation time (Smith \& Geider 1985). Illumination was by tungsten-halogen lamp, filtered through a blue acrylic screen. The incubator design permitted precise determination of the PFR experienced by the samples, using the Biospherical Instruments $4 \pi$ quantum probe, Radioactive bicarbonate solution (New England Nuclear product, treated by us with UV radiation to eliminate any contaminating organic ${ }^{14} \mathrm{C}$ and then sterilized by autoclaving) was added at $1.0 \mu \mathrm{Ci}$ $\mathrm{ml}^{-1}$ from a stock solution of $1.0 \mathrm{mCi} \mathrm{ml}^{-1}$ Incubations were terminated by acidification (to a final concentration of $1.25 \mathrm{~N} \mathrm{HCl}$ ), samples were de-gassed for $1 \mathrm{~h}$, then neutralized (with $\mathrm{NaOH}$ ) and mixed with a watersoluble scintillation cocktail. Activity was measured by liquid scintillation spectroscopy with external standards correction for quenching.

Both oxygen-based and ${ }^{14} \mathrm{C}$-based photosynthetic light responses were fitted by non-linear least squares regression.

Light transmission. On each sampling date, meas- 
urements of downwelling photon fluence rate (PFR) immediately beneath the ice $\left(I_{u}\right.$, Equation 1) were taken using a LI-COR Inc. cosine collector quantum probe, measuring in the 400 to $700 \mathrm{~nm}$ band (PAR). The probe was deployed on an arm of $1 \mathrm{~m}$ length to avoid interference from the sampling hole, and was raised as gently as possible to the ice-water interface in order to minimize disturbance of the ice algal layer. Total downwelling solar radiation was measured simultaneously by Eppley pyranometer at Resolute airport, about $10 \mathrm{~km}$ distant (Environment Canada Atmospheric Environment Service 1982), and converted to PAR equivalent (I' of Equation 1) assuming that PAR is onehalf of total solar radiation. The ratio could have been as low as 0.42 but might be expected to average closer to 0.50 due to the typically dry arctic air masses (Baker \& Frouin 1987). Inaccuracy in the conversion of total to PAR radiation at the snow surface will influence interpretation of our estimates of the parameters for snow and ice albedo in Equation 1, but should not affect either the other parameters or the accuracy of estimated light reaching the ice algae.

The thickness of the ice sheet varied little during our study. It was therefore not possible to discriminate the effects of diffuse attenuation by the ice sheet from the effects of reflection from the ice surface, so the parameters a and $k_{i}$ (Equation 1) were fitted as a single constant term ( $\mathrm{a}+\mathrm{k}_{1} \cdot \mathbf{Z} \mathrm{i}_{1}$ Table 1). Multiple linear least squares regression (Bevington 1969) of the observed $\left[\ln \left(\mathrm{I}_{\mathrm{u}} / \mathrm{I}^{\prime}\right)\right]$ on corresponding observed values of $\mathrm{Z}_{\mathrm{s}}$ and [Chl] yielded the parameter estimates summarized in Table 1.

\section{RESULTS}

\section{Light transmission}

Light transmission through ice, snow and algae in 1985 was clearly related to both the depth of snow cover and to the areal pigment concentration (Fig. 2). Our simple light transmission model (Equation 1) provided a highly significant fit to the data and explained $93 \%$ of the variation. We excluded a single point representing the peak observed standing crop, $110 \mathrm{mg} \mathrm{m}^{-2}$ of chlorophyll a under thin snow cover because its presence caused unacceptable pattern in the residuals of the model against [Chl]. The pattern, and implied lack of fit, disappeared when the point was removed, and the residuals were also free of pattern when plotted against snow cover depth. The chief effect of excluding the point was to increase $\mathrm{k}_{\mathrm{chl}}$ from 0.028 to the final value of $0.035 \mathrm{~m}^{2} \mathrm{mg}^{-1}$ (Table 1). This suggested that $\mathrm{k}_{\mathrm{ch}}$ might decrease at the higher [Chl] values, but the single point was inadequate to resolve such a trend.

Transmission measurements were made again in 1986 , with the fitted model explaining $83 \%$ of the variation. The 1986 sampling was largely limited to 2 snow depths (thin snow cover, with or without the natural snow cover removed immediately before the light measurements) so the data base was more limited with regard to snow effects. The dynamic range in [Chl] was nearly twice as large in 1986 as in 1985, however, with peak crops exceeding $200 \mathrm{mg} \mathrm{m}^{-2}$ of chlorophyll $a$. The fitted value of $0.0116 \mathrm{~m}^{2} \mathrm{mg}^{-1}$ for $k_{\mathrm{chl}}$ in 1986 (Table 1 ) therefore
Fig. 2. Observed under-ice transmittance for 1985 versus areal chlorophyll standing crop, with the fitted model (Table 1) shown by solid lines. Snow depths were 0 $\mathrm{cm}, 2$ to $4 \mathrm{~cm}, 8$ to $12 \mathrm{~cm}$ and 18 to $22 \mathrm{~cm}$

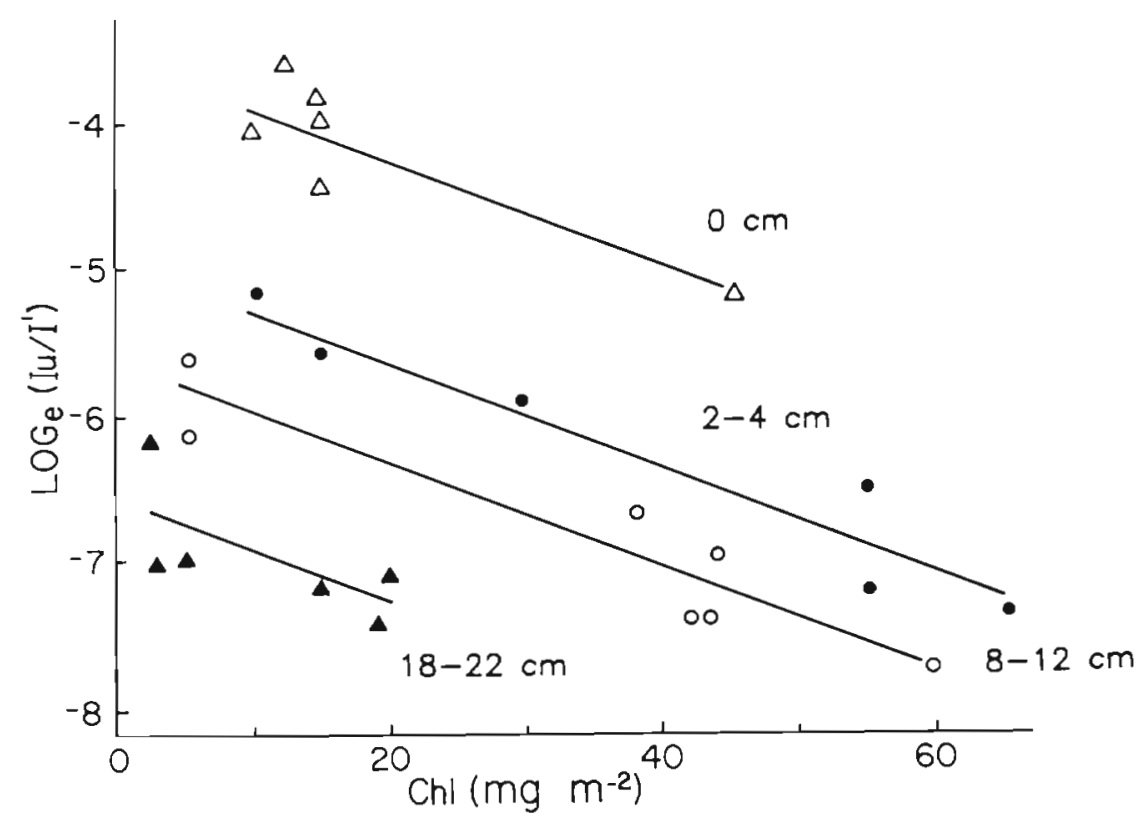


Table 1. Parameters (and their standard errors, SE) of a model for transmission of light through ice and snow in 1985 ( $n=25)$ and $1986(n=43)$ near Resolute, N.W.T Model (Equation 1) and parameters are explained in the Introduction; they were fitted by multiple linear regression. Fitted values of the model are shown for 1985 in Fig. 3

\begin{tabular}{|lllcl|}
\hline \multirow{2}{*}{ Parameter } & \multicolumn{2}{c}{1985} & \multicolumn{2}{c}{1986} \\
& Value & \multicolumn{1}{c}{$\mathrm{SE}$} & Value & $\mathrm{SE}$ \\
\hline $\mathrm{a}+\mathrm{k}_{\mathrm{i}} \mathrm{Z}_{\mathrm{i}}$ & 2.469 & 0.356 & 3.277 & 0.332 \\
$\mathrm{k}_{\mathrm{chll}}\left(\mathrm{m}^{2} \mathrm{mg}^{-1}\right)$ & 0.0350 & 0.0044 & 0.0116 & 0.0010 \\
$\mathrm{k}_{\mathrm{s}}\left(\mathrm{m}^{-1}\right)$ & 9.44 & 1.47 & 10.75 & 3.11 \\
$\mathrm{c}$ & 1.134 & 0.254 & 0.570 & 0.172 \\
$\mathrm{a}+\mathrm{k}_{\mathrm{i}} \mathrm{Z}_{\mathrm{i}}+\mathrm{c}$ & 3.603 & 0.437 & 3.847 & 0.374 \\
\hline
\end{tabular}

might indeed indicate a decrease at higher values of [Chl], perhaps as a consequence of spectral narrowing. We tried to confirm this inference by fitting the transmission model only to those 1986 data for which [Chl] was less than $80 \mathrm{mg} \mathrm{m}^{-2}$, anticipating a higher value of $\mathrm{k}_{\mathrm{chl}}$. The fitted $\mathrm{k}_{\mathrm{chl}}$ changed only to $0.0102 \mathrm{~m}^{2} \mathrm{mg}^{-1}$, however, nor did the residuals of the full data set reveal any pattern suggestive of declining $\mathrm{k}_{\mathrm{chl}}$ at higher [Chl]. Except for the single point in the 1985 data, therefore, we could find no direct evidence in our data set for a systematic decrease of $\mathrm{k}_{\mathrm{chl}}$ at higher values of standing crop

Variation in the fitted values of $\left(a+k_{i} \cdot Z_{1}\right)$ and (c) between 1985 and 1986 was not quite significant at the $95 \%$ confidence level (Table 1), but the direction of the differences suggests that freshly-cleared ice (1986) has a higher albedo than ice kept continuously free of snow (1985). The fitted value for $k_{\mathrm{s}}$ was very similar between years (Table 1 ).

\section{Photosynthesis and metabolism}

Results of the experiments on oxygen exchange were pooled to form a common estimate of the relationship between net primary production and irradiance (Fig. 3). The data were pooled because individual experiments yielded only 5 points, too few for meaningful regressions, and we sought to determine a characteristic growth efficiency for the cells. Most of the measurements were on populations from low (2 to $4 \mathrm{~cm}$ ) snow cover, but populations from heavier snow covers were also sampled twice. In all, the observations represent populations sampled from the beginning of May to early June, 1985.

Oxygen production rates represent net production (see Discussion), and so were fitted to Equation 4, with the addition of a respiration term $R^{B}$, by nonlinear least squares regression (Fig. 3). The residuals showed little trend against irradiance, indicating that the function was a reasonable description of the data. Growth efficiency $\left(1-\mathrm{R}^{\mathrm{B}} / \mathrm{P}_{\mathrm{m}}^{\mathrm{B}}\right)$ estimated from the fitted parameters was $87 \%$ (with a standard error of $5.7 \%$ calculated by propagating the error in $R^{B}$ and $\mathrm{P}_{\mathrm{m}}^{\mathrm{B}}$; Bevington 1969). There was no indication of photoinhibition at any irradiance up to the maximum of $33 \mu \mathrm{E} \mathrm{m}^{-2} \mathrm{~s}^{-1}$ used in the oxygen experiments.

The oxygen experiments could not resolve possible differences in photosynthetic response among populations from different snow covers. ${ }^{14} \mathrm{C}$ experiments offered much greater resolution of the light response (24 different PFR per curve), and the results of fitting Equation 4 are summarized in Table 2.

The photosynthetic parameters did not vary significantly among populations from different depths of

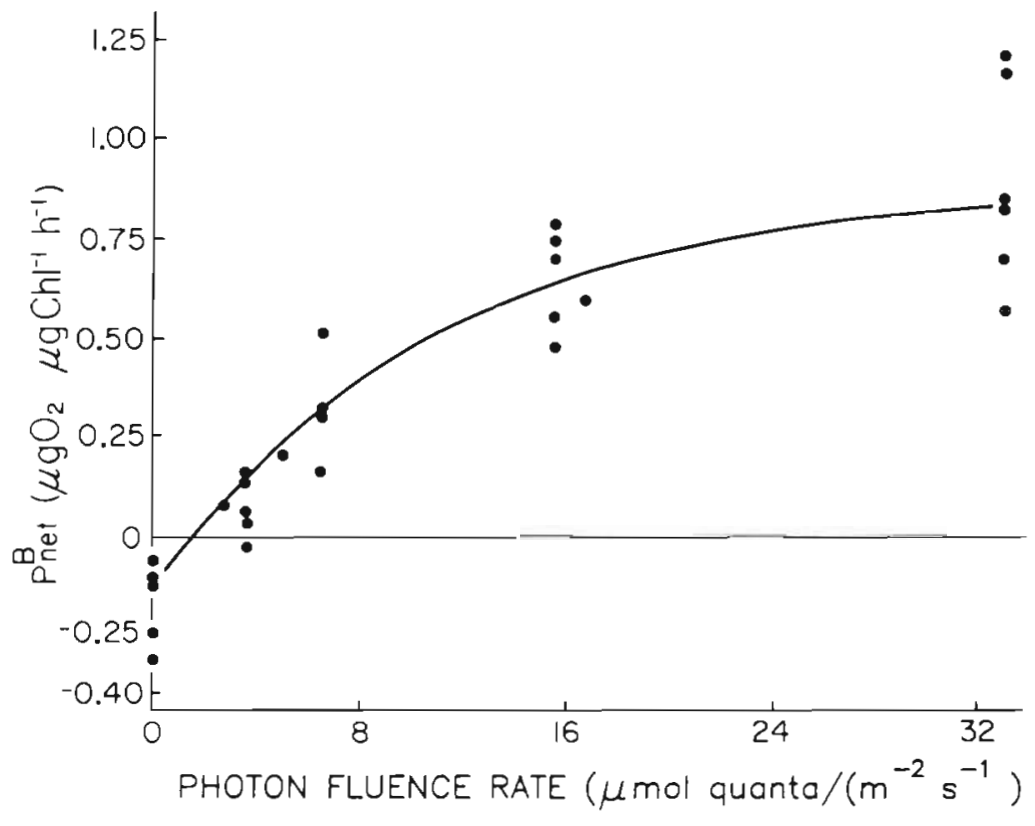

Fig. 3. Net oxygen evolution rate of ice algae as a function of $\mathrm{PFD}$, together with the fitted model: $\mathrm{P}_{n}^{\mathrm{B}}=\mathrm{P}_{\mathrm{m}}^{\mathrm{B}} \cdot\left[1-\exp \left(-\mathrm{I} / \mathrm{I}_{\mathrm{k}}\right)\right]-\mathrm{R}^{\mathrm{B}}$ The fitted parameter values and their standard errors were $1.010 \pm 0.093$ for $P_{m i}^{B} 10.87 \pm 3.01$ for $I_{k} ;$ and $0.130 \pm 0.059$ for $R^{B}$ 
Table 2. Parameters ( $\pm \mathrm{SE}$ ) of the photosynthetic light response (Equation 4) of Arctic ice algae, measured by tracer carbon assimilation in 1985. Number $n$ is the number of photosynthetic light response curves (24 rate measurements each) used to calculate the mean parameter values shown

\begin{tabular}{|c|c|c|}
\hline \multirow[t]{2}{*}{ Parameter } & \multicolumn{2}{|c|}{ Snow cover $(\mathrm{cm})$} \\
\hline & 0 & $2-22$ \\
\hline$P_{i 1}^{\mathrm{B}}$ & $1.170 \pm 0.844$ & $0.600 \pm 0.130$ \\
\hline$\alpha^{\cdots}$ & $0.061 \pm 0.047$ & $0.125 \pm 0.030$ \\
\hline$I_{k} \cdots$ & $19.1 \pm 1.7$ & $4.8 \pm 0.6$ \\
\hline$n$ & 5 & 17 \\
\hline \multicolumn{3}{|c|}{$\begin{aligned} & \cdot \mu \mathrm{gC}(\mu \mathrm{gChl} a)^{-1} \mathrm{~h}^{-1} \\
\cdots & \mu \mathrm{gC}(\mu \mathrm{gChla})^{-1} \mathrm{~h}^{-1}\left(\mu \mathrm{mol} \text { quanta } \mathrm{m}^{-2} \mathrm{~s}^{-1}\right)^{-1} \\
\cdots & \mu \mathrm{mol} \text { quanta } \mathrm{m}^{-2} \mathrm{~s}^{-1}\end{aligned}$} \\
\hline
\end{tabular}

snow cover ( $p>0.05$, multiple range $t$-test) but the populations from the cleared area had significantly higher $\mathrm{P}_{\mathrm{m}}^{\mathrm{B}}$, lower $\alpha$ and higher $\mathrm{I}_{\mathrm{k}}$ than populations from snow-covered areas $(p<0.05$, paired $t$-test). We therefore used the mean parameter estimates for all the snow-covered populations, but a separate mean value for the clear populations (Table 2). The standard errors for $\mathrm{P}_{\mathrm{m}}^{\mathrm{B}}$ and $\alpha$ were large, especially for the clear populations, because the parameter values varied among sampling dates. The parameters did not increase or decrease systematically throughout the growth season, but instead appeared to oscillate in phase with the fortnightly rhythm of tidal amplitude (Cota \& Horne unpubl.). Because $\mathrm{P}_{\mathrm{n}}^{\mathrm{B}}$ and $\alpha$ co-varied, the standard error of $\mathrm{I}_{\mathrm{k}}$ was relatively small (Table 2 ).

\section{Standing crops and production}

$B_{\max }$ was predicted from Equation 9, with $I_{0}$ calculated from the fitted light transmission model (Table 1) and downwelling incident solar radiation (I', PAR) averaged over $3 \mathrm{~d}$ periods to smooth the variations imposed by changing weather conditions. Over the main growth season (roughly Apr 1 to Jun 1), the resulting values for $I_{0}\left(\mu \mathrm{E} \mathrm{m}^{-2} \mathrm{~s}^{-1}\right)$ ranged from about 14 to 40 (clear patch), 3 to 10 ( 2 to $4 \mathrm{~cm}$ snow cover), 1.6 to $6(8$ to $12 \mathrm{~cm}$ ) and 0.7 to $2(18$ to $22 \mathrm{~cm})$. There was little difference in $\mathrm{I}_{0}$, under comparable snow covers, between 1985 and 1986.

$B_{\max }$ increased during the main algal growth season, but most of the increase ocurred before May 1 (Julian day 121 , Figs. 4 and 5) with relatively stable values thereafter. $B_{\max }$ increased with decreasing snow depth, except that populations growing under areas kept clear of snow were predicted to have a $B_{\max }$ no larger than those under thin snow cover, a consequence of their elevated values of $I_{k}$ (Table 2). The predicted maximum crops were 70 to 80 and 200 to $250 \mathrm{mg} \mathrm{m}^{-2}$ of chlorophyll a under the lower snow covers in 1985 and 1986, respectively, reflecting the smaller value of $k_{\text {chl }}$ in 1986 .

$\mathrm{B}_{\max }$ appeared to be a realistic upper limit to the standing crops observed under natural snow cover in both 1985 and 1986 (Figs. 4 and 5). Instances of higher crops were observed, but were never observed to be sustained; the thin ( 2 to $4 \mathrm{~cm}$ ) snow cover populations in 1985 in particular appeared to vary about $B_{\max }$ through most of May. Populations under heavy snow cover in 1985 achieved a large standing crop on our last sampling date, but it is doubtful that the peak was sustained. Ice algae began to shed from the ice into the water column in early June (Smith et al. 1987) signalling the decline of the ice algal bloom shortly after the end of our 1985 observation period (Fig. 4).

$B_{\max }$ greatly overestimated the crops actually attained in the artificially cleared area (Fig. 4). The observed crops in the cleared area were also lower than those under low or moderate snow cover. According to the measured photosynthetic light responses (Table 2) the algae should not have been photoinhibited in the clear area.

$P_{n}$ was calculated from Equation 6, and the resulting values for net photosynthetic carbon production rate ( $\mathrm{mgC} \mathrm{m}^{-2} \mathrm{~d}^{-1}$ ) were integrated by linear interpolation to calculate the expected rate of particulate organic Carbon (POC) accumulation in the ice (Figs, 5 and 6). POC observed under natural snow cover in 1985 roughly paralleled the calculated values, but tended to be larger than the model predictions early in the growth season. In the late season, predicted POC accumulation exceeded the observed for 2 to $12 \mathrm{~cm}$ snow cover, but was less than the observed for 18 to 22 $\mathrm{cm}$ snow cover (Fig. 6). The calculated accumulation of POC was much larger than that observed under bare ice through most of the growth season.

Calculated POC accumulation was larger than the observed in 1986 (Fig, 5). The 1986 POC values were not measured directly, but were calculated from the observed chlorophyll crops and a POC:Chlorophyll a ratio of 21.9 derived from biochemical assays (Smith et al. 1988). The 1985 ratio was about 50 for algae under thin or no snow cover but even the larger ratio would not eliminate the disparity.

$P_{\text {opt }}$ the light-limited upper bound to production, was calculated by evaluating Equation 6 for $[\mathrm{Chl}]=\mathrm{B}_{\max }$ (Table 3). $P_{\text {opt }}$ was much greater in 1986 than 1985, $P_{n}$ attained $P_{o p t}$ by definition, for all those populations for which observed [Chl] equalled $B_{\max }$. The season-average values of $P_{n}$, calculated by dividing the predicted accumulation of POC (Figs. 5 and 6) by the length of the observation period, were less than $P_{\text {opt }}$ because [Chi] was often less than $B_{\max }$ (Table 3 ). 


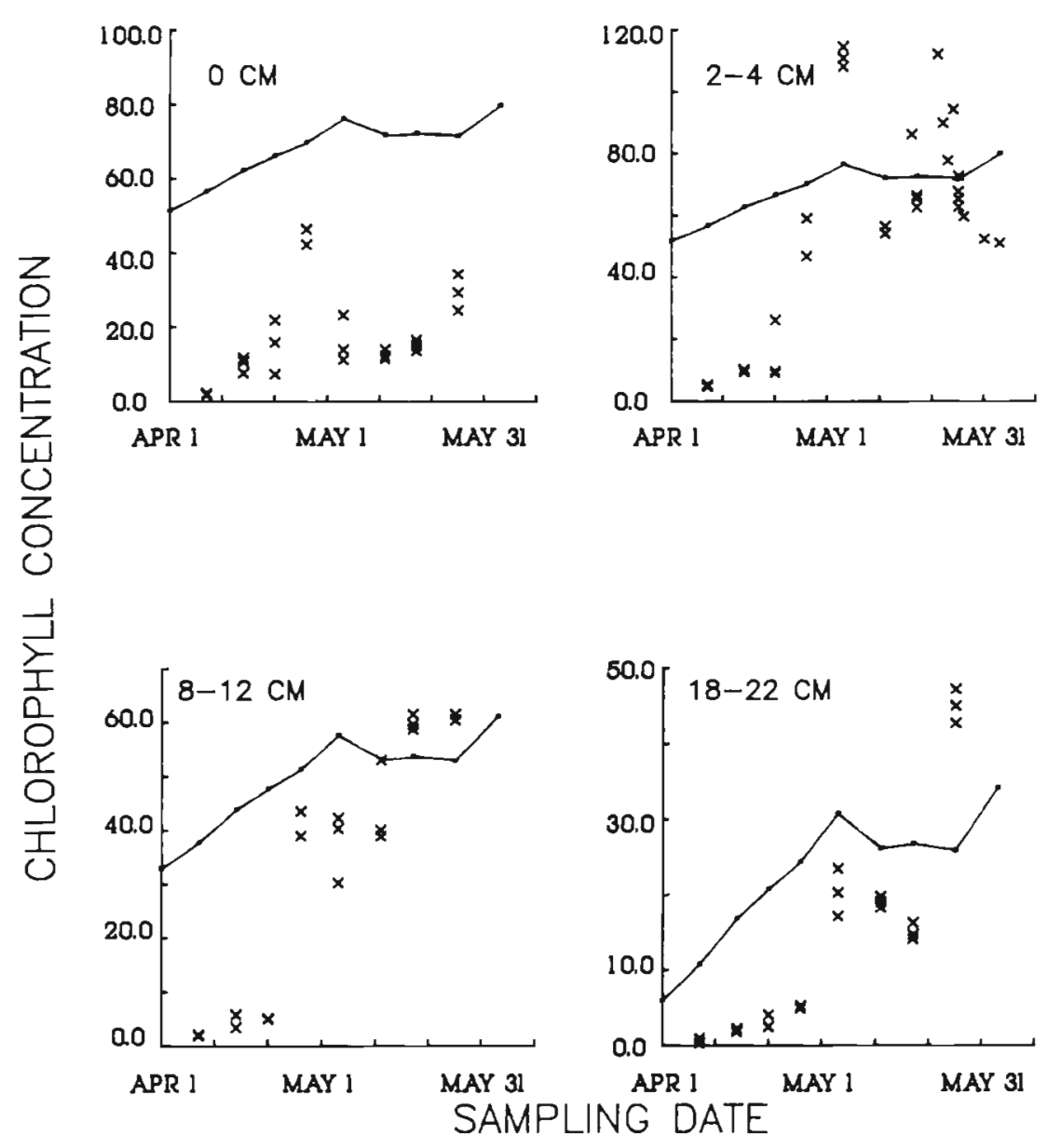

Fig. 4. Observed seasonal dynamics of chlorophyll a $\left(\mathrm{mg} \mathrm{m}^{-2}\right)$ in sea ice in 1985 under 4 different depths of snow cover. Solid lines: $\mathrm{B}_{\text {max }}$ (Equation 9). Note different scales for chlorophyll among panels
On season-average basis, observed rates of $\mathrm{POC}$ accumulation were similar to the rates calculated from $P_{n}$ for natural snow cover in 1985, and the maximum rates of POC accumulation observed during the observation period approached or even exceeded $\mathrm{P}_{\text {opt }}$ (Table 3). The difference between observed POC accumulation and calculated production provides an estimate of potential export from the ice algal community, and ranged from a small negative value for heavy snow cover to a much larger positive value for the clear area in 1985 (Table 3). The export values so calculated are for the period preceding the decline of the algal bloom, when the major release of cells from the ice occurs. In 1986, the calculated production was much greater than the observed POC accumulation, leading to a large predicted export rate compared to any of the other populations we encountered (Table 3).

\section{Other arctic sites}

To calculate $B_{\max }$ corresponding to crops reported from other locations in the arctic (Table 4), values of incident solar radiation for all locations except Resol- ute, 1984 and Point Barrow, Alaska, were obtained from reasonably proximate Environment Canada weather stations, in the same units and from the same instrumentation as the Resolute data. We used the $30 \mathrm{yr}$ climatic norms rather than values specific to the particular years studied, a minor inaccuracy. Incident solar radiation, according to the climatic norms, ranged only about $\pm 10 \%$ among all the locations at latitude $>60^{\circ} \mathrm{N}$ during the ice algal growth season. Incident radiation for Point Barrow was estimated from the Environment Canada Inuvik weather station. The Resolute 1984 calculations, like those in 1985 and 1986 , were based on daily radiation at Resolute. The parameter values used to predict $B_{\max }$ (Equation 6) were those that we estimated and then used in our predictions for crops near Resolute in 1985.

All the literature values for arctic ice algal standing crop (except for one under deep snow) were less than the calculated $B_{\max }$ (Table 4 ). The disparity would be yet greater had we used our 1986, rather than our 1985 , value for $\mathrm{k}_{\mathrm{ch} \text {. }}$. It would seem that our calculated maxima are indeed upper limits that published results to date do not surpass with any regularity.

Table 4 includes values for Resolute in 1984, col- 

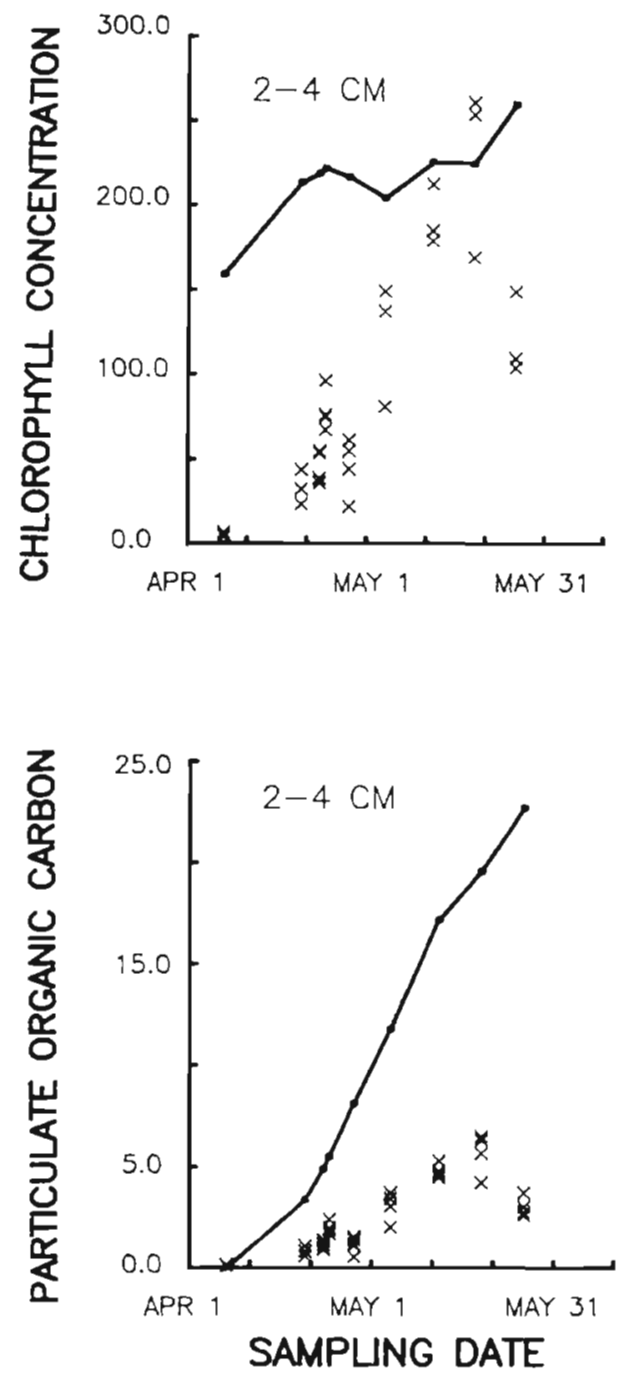

Fig. 5. Observed seasonal dynamics of chlorophyll a (mg ${ }^{-2}$ upper panel) and POC (mgC m $\mathrm{m}^{-2}$, bottom panel) in sea ice covered with 2 to $4 \mathrm{~cm}$ of snow in 1986. Line in the upper panel: $B_{\max }$ line in the lower panel: cumulative $\mathrm{POC}$ calculated from net photosynthetic production rate, $P_{n}$

lected at sites closer to shore than in subsequent years. A transect was also sampled in 1984, from near-shore to several $\mathrm{km}$ offshore. Sampling again spanned the main algal growth season, as it did in 1985 and 1986, and the values reported are the maximum observed. Seasonal means follow similar patterns. Maximum crops were, like the literature values, less than $B_{\max }$. As the range of values for the $3 \mathrm{~cm}$ snow cover shows (Table 4 ), however, the standing crops increased about 4 -fold in the offshore direction, a difference greatly exceeding the statistical uncertainty in the crop estimates. The abundance of amphipods, known consumers of ice algae, was simultaneously observed to decrease in the offshore direction (G. F. Cota unpubl.).

\section{DISCUSSION}

Previous studies in the Arctic have demonstrated positive correlations between light availability and ice algal abundance and production rates (Clasby et al. 1976, Horner \& Schrader 1982) but have not pursued the effects of different light availabilities throughout the growth season. We have shown that ice algae growing under natural snow cover at our site near Resolute in 1985 and 1986 attained crops equalling the theoretical maximum imposed by self-shading (Figs. 4 and 5), and that through the main growth season of 1985 both calculated net production and observed POC accumulation rates in situ varied directly with light availability (Table 3 ). Crop sizes and production rates of ice algae (in bottom ice) also varied directly with available light through most of the growth season in McMurdo Sound, Antarctica (Grossi et al. 1987) and the early to mid season in Hudson Bay (Gosselin et al. 1986). Such results demonstrate that shortage of light is commonly a limiting factor to ice algal growth in a variety of polar marine ecosystems.

The crops observed under artificially cleared snow in 1985 (Fig. 4 and 6) and at sites elsewhere in the Arctic (Table 4) were much less than the theoretical maximum. The potential inadequacies of conventional sampling techniques (Clasby et al. 1976, Welch et al. 1988) are not systematically related to the apparent discrepancies of standing crops, but 3 other general factors could be involved. Our light transmission model might overestimate light availability in some cases, as discussed below. Alternatively, the efficiency of light use might differ from the values in the model; in particular, $\mathrm{k}_{\mathrm{ch} l}$, $\mathrm{I}_{\mathrm{k}}$ and $\mathrm{R}^{\mathrm{B}} / \mathrm{P}_{\mathrm{m}}^{\mathrm{B}}$ might be larger. The remaining major possibility is that natural populations are subject to additional losses (Apollonio 1965, Grossi et al. 1987) or to growth-limiting factors (Maestrini et al. 1986, Smith et al. 1987) other than light. In at least 2 cases, our results point to increased losses as important factors in addition to the available light in determining ice algal abundance.

Diminished algal crop sizes at high irradiance levels, as in our experimental snow-free area, have been reported before and attributed variously to photosynthetic inhibition (Gosselin et al. 1986) and to physical deterioration of the ice and bleaching of the algae (Apollonio 1961, 1965). Our measurements failed to reveal photoinhibition of photosynthesis in the clear ice populations, while direct measurements of POC production showed that bleaching was only a partial explanation (Fig. 6, Table 3). The light transmission model is not likely to be seriously wrong, since it was fitted, in part, to data from the clear patch without obvious systematic error. In fact, no error in our model would explain why observed pigment and carbon 

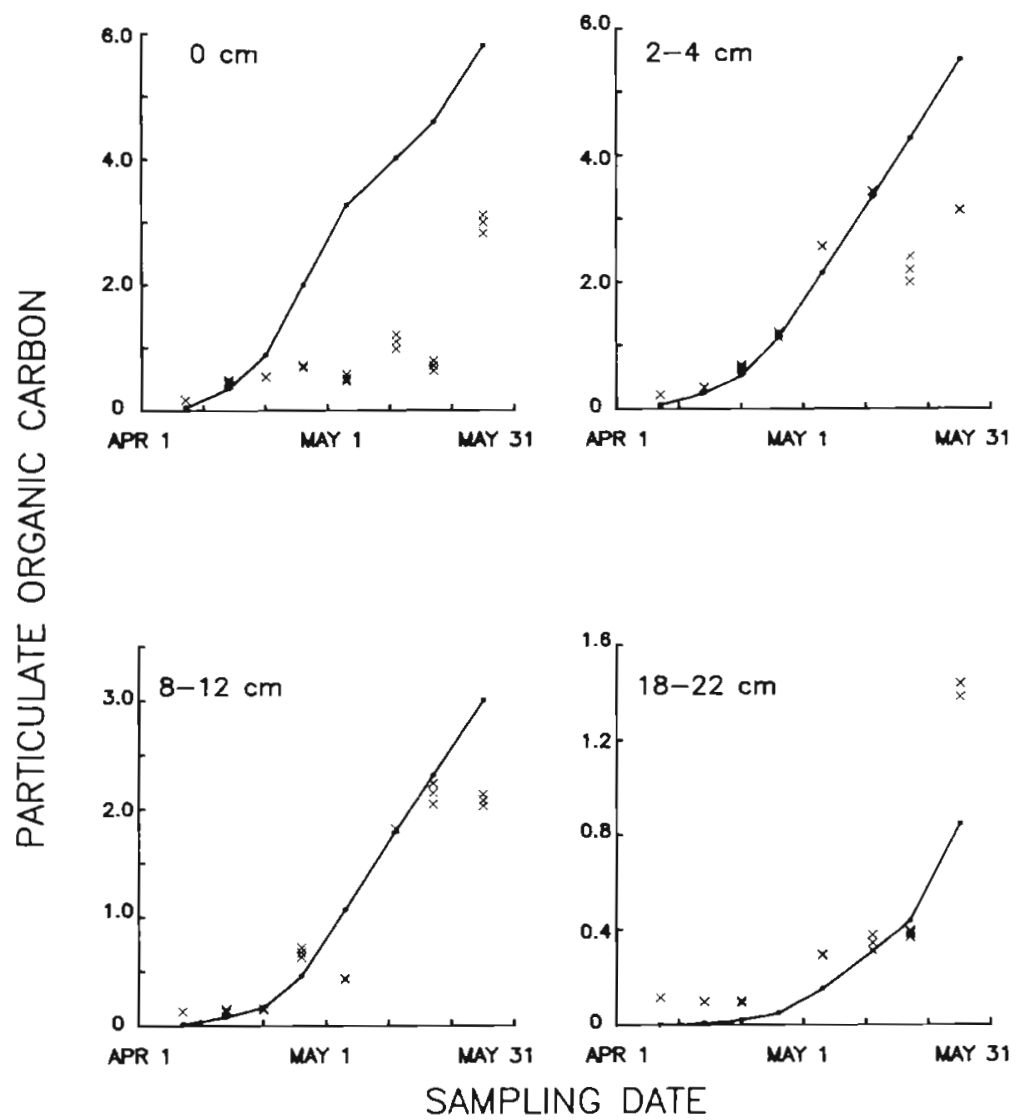

Fig. 6. Observed seasonal dynamics of POC $\left(\mathrm{mgC} \mathrm{m}{ }^{-2}\right)$ in sea ice in 1985 under 4 different depths of snow cover. Solid lines: cumulative POC calculated from net photosynthetic carbon production rate, $P_{n}$. Note different scales for POC among paneis standing crops were usually lower under snow-free ice than ice with thin snow cover Increased losses from the clear ice populations, perhaps through excessive light absorption and consequent deterioration of the ice, therefore seem the likeliest explanation. If so, production under the thinnest snow covers was poised between light limitation and light excess. The rapid increase of light penetration accompanying snow-melt can be expected to induce losses similar to those we infer under the experimental clear patch, and may be instrumental in ending the ice algal bloom (Homer 1985).

The 1984 Resolute results present the other case for control of crops by loss rates. The observed crops were again smaller than the theoretical maximum, but the variation of crop sizes and amphipod abundance along the sampling transect suggested significant control of algal crops by amphipod grazing (Cross 1982). Apollonio (1965) reported the presence of amphipods in some ice cores, and also speculated that grazing influenced algal crop sizes in Frobisher Bay. It seems likely that amphipod grazing may have influenced many of the results culled from the literature (Table 4), which were also often from sites either nearshore or in shallow water columns. Both characteristics favour higher amphipod abundance in the Resolute vicinity (Welch pers. comm.)

For sites other than Resolute, the low crops observed relative to $B_{\max }$ (Table 4 ) may indicate that light alone is not limiting to maximum crop size and production at those sites. Alternatively, our model's theoretical maximum may be too high, i.e extrapolation of our estimated parameter values to other sites and years may be unjustified. Our own observations in 1985 and 1986 showed that the theoretical maximum can vary widely even at the same site due solely to variability of the chlorophyll a-specific diffuse attenuation coefficient. Photosynthetic parameters and algal metabolism may also vary among sites and through the growth season in various ice communities (Cota 1985, Gosselin et al. 1985, 1986, Palmisano et al. 1985). Photoadaptive changes in photosynthetic parameters, including respiration rates and cell composition, could significantly alter the fundamental underpinnings of the model as expressed in Fig. 1. We were unable to demonstrate significant variation in the average values of photosynthetic parameters among populations grown under different snow covers and light regimes near Resolute, however, except for those under the (artificially) cleared areas. Photoadaptive differences probably do exist 
Table 3. Carbon production rates of ice algae near Resolute, N.W.T $P_{\text {opt }}=$ theoretical maximum net production rate; $P_{n}=$ in situ production rate calculated (Equation 6 ) for the observed populations; $P_{c}=$ observed change of particulate organic carbon concentration in the ice. Export is the difference between production ( $P_{n}$ average) and accumulated POC $\left(P_{c}\right.$ average), representing loss of algal biomass from ice during growth season. Ranges are standard deviation, as percent of the mean, based on triplicate measurements of algal standing crop (for $\mathrm{P}_{\mathrm{n}}$ ) or POC concentration (for $\mathrm{P}_{\mathrm{c}}$ ) or both (for Export), so annual and daily rates have the same error range. Observations are from 1985 season except as noted

\begin{tabular}{|c|c|c|c|c|c|}
\hline & \multicolumn{5}{|c|}{ Snow cover $(\mathrm{cm})$} \\
\hline & 0 & $2-4$ & $8-12$ & $18-22$ & $\begin{array}{c}2-4 \\
(1986)\end{array}$ \\
\hline \multicolumn{6}{|c|}{ Daily rates $\left(\mathrm{mgC} \mathrm{m}^{-2} \mathrm{~d}^{-1}\right)$} \\
\hline$P_{\text {opt }}$ & 323.7 & 316.0 & 156.5 & 32.96 & 953.4 \\
\hline \multirow{2}{*}{$\mathrm{P}_{\mathrm{n}}$ (average) } & 116.8 & 121.2 & 66.3 & 20.61 & 462.9 \\
\hline & \pm 8.2 & \pm 6.8 & \pm 4.2 & \pm 9.6 & \pm 18.0 \\
\hline \multirow{2}{*}{$P_{C}($ maximum $)$} & 283.2 & 198.9 & 199.5 & 132.2 & 319.6 \\
\hline & \pm 6.0 & \pm 2.5 & \pm 5.0 & \pm 5.6 & \pm 7.7 \\
\hline \multirow[t]{2}{*}{ (Average) } & 58.5 & 94.2 & 50.3 & 27.6 & 132.2 \\
\hline & \pm 5.6 & \pm 4.8 & \pm 7.6 & \pm 6.6 & \pm 18.0 \\
\hline \multicolumn{6}{|c|}{ Annual rates for $50 \mathrm{~d}$ growth season $\left(\mathrm{gC} \mathrm{m}^{-2} \mathrm{yr}^{-1}\right)$} \\
\hline $\mathrm{P}_{\mathrm{n}}$ & 5.8 & 6.1 & 3.3 & 1.15 & 23.1 \\
\hline$P_{c}$ & 2.9 & 4.7 & 2.5 & 1.40 & 6.6 \\
\hline \multirow[t]{2}{*}{ Export } & 2.9 & 1.4 & 0.8 & -0.25 & 16.5 \\
\hline & \pm 16.4 & \pm 52.5 & \pm 27.9 & \pm 28.2 & \pm 26.0 \\
\hline
\end{tabular}

Table 4. Collected literature reports of areal concentration of ice algae chlorophyll in arctic locations, together with the predicted maximum possible light-limited concentrations, $B_{\text {nax, }}$ and the calculated PFD reaching the algae, $I_{0}$ ( $\mu$ mol quanta $\mathrm{m}^{-2} \mathrm{~s}^{-1}$ ). Sources are: Jones Sound, Apollonio (1961, 1965); Frobisher Bay, Grainger (1977); Point Barrow, Clasby et al. (1976); Barrow Strait, Robeson Channel and Hudson Bay Dunbar and Acreman (1980); Resolute 1984, G. F. Cota (unpub.)

\begin{tabular}{|c|c|c|c|c|c|}
\hline Location & $\begin{array}{c}\text { Thicki } \\
\text { ice } \\
(\mathrm{cm})\end{array}$ & $\begin{array}{l}\text { ness of } \\
\text { snow } \\
(\mathrm{cm})\end{array}$ & $\mathrm{I}_{0}$ & $\begin{array}{l}\text { Chlorophy } \\
\text { observed } \\
\left(\mathrm{mg} \mathrm{m}^{-2}\right)\end{array}$ & $\begin{array}{l}\text { yll a conc. } \\
\qquad B_{\max } \\
\left(\mathrm{mg} \mathrm{m}^{-2}\right)\end{array}$ \\
\hline Jones S. & 165 & 21 & 1.62 & 23.0 & 30.0 \\
\hline Jones S. & 190 & 10 & 4.58 & 23.0 & 60.0 \\
\hline Frobisher & 150 & $5-20$ & 3.00 & 4.6 & 48.0 \\
\hline Frobisher & 150 & 37 & 0.29 & 1.5 & 0.0 \\
\hline Frobisher & 150 & 10 & 3.92 & 9.1 & 55.6 \\
\hline Pt. Barrow & 162 & 5 & 6.43 & 30.0 & 69.8 \\
\hline Pt. Barrow & 162 & 5 & 6.43 & 24.0 & 69.8 \\
\hline Robeson Ch. & 194 & 1 & 10.09 & 10.3 & 82.6 \\
\hline Barrow St. & 160 & 2 & 8.93 & 13.8 & 79.2 \\
\hline Hudson Bay & 119 & 3 & 4.53 & 25.3 & 59.8 \\
\hline \multirow[t]{5}{*}{ Resolute 1984} & 180 & 0 & 34.8 & 12.2 & 77.1 \\
\hline & 180 & $3^{\circ}$ & 8.50 & 11.6 & 77.5 \\
\hline & 180 & $3^{*}$ & 8.50 & 45.6 & 77.5 \\
\hline & 180 & 10 & 4.39 & 18.3 & 58.6 \\
\hline & 180 & 20 & 1.71 & 20.7 & 31.6 \\
\hline
\end{tabular}

among populations from different natural snow covers, but were too small to be detectable with our moderate sample size. Similarly, photoadaptive differences in cell composition ratios such as chlorophyll:carbon were significant but small except for populations from the cleared areas (Smith et al. 1988). More work is required to characterize the variability and predictability of photoadaptive parameters in ice algal populations, but our data suggest that at least one important source of variability is the light attenuation parameter, $\mathrm{k}_{\mathrm{chl}}$.

Our fitted value for $\mathrm{k}_{\mathrm{chl}}$ in $1986\left(0.0116 \mathrm{~m}^{2} \mathrm{mg}^{-1}\right.$ Table 1) was similar to the mean spectral absorption coefficient recently reported for antarctic ice algae (SooHoo et al. 1987) and was likely near the minimum value that can be expected (Bannister \& Weidemann 1984). The relatively large 1985 value of $0.035 \mathrm{~m}^{2} \mathrm{ml}^{-1}$ probably reflects the problems of measuring absorption coefficients by the regression of transmittance against chlorophyll concentrations (Bannister \& Weidemann 1984), which mostly act to inflate the estimate. The strong narrowing of the light spectrum into the blue wavelengths in passage through sea ice (Grenfell \& Maykut 1977, Maykut 1985) may also contribute to a high value for $k_{\mathrm{chl}}$, but would not explain the interannual variability of $\mathrm{k}_{\mathrm{ch} \text {. }}$. Non-algal light absorbing and scattering material that co-varies with the algae, and changes in the absorbing and scattering properties of the ice itself, are likely causes of the massive change in $k_{c h l}$ between years. Spectral narrowing of light transmitted through the ice and associated algae due to algal light absorption results in a predominantly green, rather than blue, spectrum and relatively low algal absorption coefficients (Bannister \& Weidemann 1984 SooHoo et al. 1987). While our observed algal standing crops were certainly high enough to cause major spectral modification, we could not consistently demonstrate that biomass levels influenced our regression estimates of $\mathrm{k}_{\mathrm{ch}}$. We therefore have no positive evidence to suggest the factors responsible for apparently major variations in $\mathrm{k}_{\mathrm{chl}}$.

Although it is clear that our $\mathrm{k}_{\mathrm{chl}}$ cannot be regarded as an accurate estimate of the algal absorption coefficient, it should be emphasized that it is the parameter needed in order to calculate the light reaching the algae, and also the amount ultimately passing through to the water column. Algal light absorption alone appears unlikely to explain the inter-annual variations in $\mathrm{k}_{\mathrm{chl}}$. Identifying the additional components of $\mathrm{k}_{\mathrm{chl}}$ is important because the parameter is critical to the production and standing crops (Equations 6 and 9) that can be attained for a given supply of light, and its variation is one of the largest sources of uncertainty in our predictions.

Our model's fitted values for 'a' (Table 1) imply by difference an albedo for bare ice of 0.62 to 0.76 (1985 vs 
1986) if we assume a typical attenuation coefficient of $0.01 \mathrm{~cm}^{-1}$ (Thomas 1963. Grenfell \& Maykut 1977. Maykut 1985) for our average ice sheet thickness of $1.85 \mathrm{~m}$, and our fitted value for ' $\mathrm{C}$ ' would then imply an albedo of 0.86 to 0.88 for snow. Such albedos are at the high end of the range cited by Maykut (1985) but would be substantially smaller if we assumed a larger attenuation coefficient for ice from within the previously published range (ca 0.008 to $0.012 \mathrm{~cm}^{-1}$ ) or a lower factor for converting total downwelling surface radiation to PAR downwelling. Our $\mathrm{k}_{\mathrm{s}}$ values (Table 1) are definitely at the low end of the range of previously published values for dry snow 10.18 to $0.45 \mathrm{~cm}^{-1}$ : Thomas 1963, Grenfell \& Maykut 1977, Warren 1982, Maykut 1985) so we may suspect that our estimates of light transmission to the algae are generous. More such measurements are needed to meet a long-standing need for better practical models for light transmission suitable to ecological applications (Welch et al. 1987).

The rate of planktonic primary production in Arctic shelf waters has been estimated to average $27 \mathrm{gC} \mathrm{m}^{-2}$ $\mathrm{yr}^{-1}$ for a $120 \mathrm{~d}$ growth season, or $13.5 \mathrm{gC} \mathrm{m}^{-2} \mathrm{yr}^{-1}$ for a probably more realistic $60 \mathrm{~d}$ season in the High Arctic (Subba Rao \& Platt 1984). Our calculated production rates, $\mathrm{P}_{\mathrm{n}}$, thus predict that production in the ice under thin snow cover, in 1986, could equal or even exceed that in the water column (Table 3 ). Our annual production estimates should be conservative because we assumed a $50 \mathrm{~d}$ growth season (matching our main observation period) but some production undoubtedly occurs outside that interval; the 1985 rates could be twice as large if production continued throughout June. The calculated export rates (Table 3 ) predict that half or more of production can be exported even during the main algal growth season, but mainly from areas of zero or thin snow cover. In situ measurements are needed to confirm the predicted export of production to the water column near Resolute, but a significant export rate is consistent with results obtained by in situ incubations elsewhere in the Arctic and Antarctic. Grossi et al. 1987 reported an even larger proportional export, about $90 \%$ of total production in a snow-free area in McMurdo Sound. A smaller proportion, about $30 \%$, was exported from populations growing under 5 $\mathrm{cm}$ snow cover. Results from the Chukchi Sea (Clasby et al. 1976) suggest approximately $50 \%$ export, if the observed increase of chlorophyll a standing crop during the observation period is converted using a ratio of 100 mgC:mg Chlorophyll a. At Resolute, copepods have been shown to feed upon ice algae throughout the algal growth season (Conover et al. 1986), confirming that algae do reach the water column. The mechanisms of export, and the fate of the exported material, are important subjects for further study (Grossi et al. 1987).

We have previously presented evidence, from patterns of intracellular photosynthate allocation, for nutrient limitation of photosynthetic rates in the ice algal populations growing under thin snow cover in 1985 (Smith et al. 1987). The results presented here indicate that in situ production and standing crop were light limited. This seeming contradiction may reflect the vertical stratification of growth conditions, from relatively plentiful light but marginal nutrient supply at the top of the algal layer to extreme shade but better nutrient supply at the bottom. Measurements of photosynthesis in samples of the whole algal community will be influenced by cells adapted to both extremes even if, as our model assumes, light is the final limiting factor to crop size and production in situ. Results from Hudson Bay (Gosselin et al. 1986, Maestrini et al. 1986) and the bottom-ice community in Antarctica (McConville et al. 1985, Palmisano \& Sullivan 1985, Grossi et al. 1987) have also given indications of both light and nutrientlimitation, and may similarly reflect the heterogeneity of physiological condition in natural populations. Ice algae are likely to adapt to strong vertical gradients in physical and chemical conditions, in their photosynthetic parameters, nutrient utilization kinetics, and other physiological features. Such adaptation may prove crucial to a more complete understanding of ice algae ecology.

Acknowledgements. We thank the staff of the Polar Continental Shelf Project and our colleagues from the Freshwater Institute for assistance and cooperation, and $\mathrm{T}$. Platt, $\mathrm{L}$ Legendre, and J. SooHoo for comments on earlier drafts.

\section{LITERATURE CITED}

Apollonio, S. (1961). The chlorophyll content of arctic sea-ice Arctic 14: 197-200

Apollonio, S. (1965). Chlorophyll in arctic sea i.ce. Arctic 18 $118-122$

Baker, K. S., Frouin, R. (1987). Relation between photosynthetically available radiation and total insolation at the ocean surface under clear skies. Limnol. Oceanogr. 32 $1370-1377$

Bannister, T T., Weidemann, A. D. (1984). The maximum quantum yneld of phytoplankton photosynthesis in situ. J. Plankton Res. 6: 275-294

Bates, S. S., Cota, G. F. (1986). Fluorescence induction and photosynthetic responses of arctic ice algae to sample treatment and salinity. J. Phycol. 22: 421-419

Bevington, P. R. (1969). Data reduction and error analysis for the physical sciences. McGraw-Hill Lid., Toronto

Clasby, R. C., Alexander, V., Horner, R. A. (1976). Primary productirity of sea ice algae. In: Hood, D. W., Burrell, D. C. (eds.) Assessment of the arctic marine environment. Inst. Mar. Sci., Univ. of Alaska, p. 289-304

Conover, R. J., Herman, A. W., Prinsenberg, S. J., Harris, L. (1986). Distribution of and leeding by the copepod Pseudocalanus under fast ice durng the arctic spring. Science 232: 1245-1247 
Cota, G. F. (1985). Photoadaptation of high arctic ice algae. Nature, Lond. 315: 219-222

Cota, G. F., Prinsenberg, S. J., Bennett, E. B., Loder, J. W., Lewis, M. R., Anning, J. A., Watson, N. H. F., Harris, L. R. (1987). Nutrient flux during extended blooms of arctic ice algae. J. Geophys. Res. 92 (C2): 1951-1962

Cross, W. E. (1982). Under ice biota at the Pond Inlet ice edge and in adjacent fast ice areas during spring. Arctic 35: $13-27$

Dunbar, M. J., Acreman, J. C. (1980). Standing crops and species composition of diatoms in sea ice from Robeson Channel to the Gulf of St. Lawrence. Ophelia 19: 61-72

Environment Canada, Ottawa, Atmospheric Environment Service. (1982). Canadian Climatic Normals, Volume 1: Solar Radiation, 1951-1980

Gosselin, M., Legendre, L., Demers, S., Ingram, R. G. (1985). Responses of sea ice microalgae to climatic and fortnightly tidal energy inputs (Manitounuk Sound, Hudson Bay). Can. J. Fish. Aquat. Sci. 42: 999-1006

Gosselin, M., Legendre, L., Therriault, J.-C., Demers, S. Rochet, M. (1986). Physical control of the horizontal patchiness of sea-ice microalgae. Mar. Ecol. Prog. Ser 29 289-298

Grainger, E. H. (1977). Primary production in Frobisher Bay, Arctic Canada. In: Dunbar, M. J. (ed.) Marine production mechanisms. Cambridge Univ. Press, Cambridge, p. 9-30

Grenfell, T., Maykut, G. A. (1977). The optical properties of ice and snow in the arctic basin. J. Glaciol. 18: 445-463

Grossi, S. M., Kottmeier, S. T., Moe, R. L., Taylor, G. T. Sullivan, C. W. (1987). Sea ice microbial communities. VI Growth and primary production in bottom ice under graded snow cover. Mar. Ecol. Prog. Ser. 35: 153-164

Horner, R. A. (1985). Ecology of sea ice microalgae. In: Horner, R. A. (ed.) Sea ice biota. CRC Press, Boca Raton, Florida, p. 83-103

Horner, R., Schrader, G. C. (1982). Relative contributions of ice algae, phytoplankton, and benthic microalgae to primary production in nearshore regions of the Beaufort Sea. Arctic 35: 484-503

Lewis, M. R., Smith, J. C. (1983). A small volume, short incubation time method for the measurement of photosynthesis as a function of incident irradiance. Mar. Ecol. Prog Ser 13: 99-102

Lewis, M. R., Warnock, R. E., Platt, T (1985). Absorption and photosynthetic action spectra for natural phytoplankton populations: implications for production in the open ocean. Limnol. Oceanogr. 30: 794-806

Maestrini, S. Y., Rochet, M., Legendre, L., Demers, S. (1986). Nutrient limitation of the bottom-ice microalgal biomass (southeastern Hudson Bay, Canadian Arctic). Limnol. Oceanogr. 31: 969-982

Maykut, G. A. (1985). The ice environment. In: Horner, R. A. (ed.) Sea ice biota. CRC Press, Boca Raton, Florida, p. 22-82

McConville, M. J., Mitchell, C., Wetherbee, R. (1985). Patterns of carbon assimilation in a microalgal community from annual sea ice, East Antarctica. Polar Biol. 4: 135-141
Palmisano, A. C., Sullivan, C. W. (1985). Pathways of photosynthetic carbon assimilation in sea ice algae from McMurdo Sound, Antarctica. Limnol. Oceanogr 30: $674-677$

Palmisano, A. C., SooHoo, J. B., Sullivan, C. W (1985). Photosynthesis-irradiance relationships in sea ice microalgae from McMurdo Sound, Antarctica. J. Phycol. 21. 341-346

Palmisano, A. C., SooHoo, J. B., Moe, R. L., Sullivan, C. W (1987). Sea ice microbial communities VII. Changes in under-ice spectral irradiance during the development of Antarctic sea ice microalgal communities. Mar. Ecol. Prog Ser. 35: 165-173

Platt, T., Gallegos, C. L., Harrison, W. G. (1980). Photoinhibition of photosynthesis in natural assemblages of marine phytoplankton. J. mar. Res. 38: 687-701

Poulin, M., Cardinal, A., Legendre, L. (1983). Response d'une communauté de diatomées de glace à un gradient de salinité (baie d'Hudson). Mar. Biol. 76: 191-202

Smith, R. E. H., Geider, R. J. (1985). Kinetics of intracellular carbon allocation in a marine diatom. J. exp. mar. Biol Ecol. 93: 191-210

Smith, R. E. H., Clement, P., Head, E. J. (1988). Biosynthesis and photosynthate allocation patterns of Arctic ice algae. Limnol. Oceanogr. (in press)

Smith, R. E. H., Clement, P., Cota, G. F., Li, W. K. W. (1987). Intracellular photosynthate allociation and the control of arctic marine ice algal production. J. Phycol. 23: $124-132$

SooHoo, J. B., Palmisano, A. C., Kottmeier, S. T., Lizotte, M. P., SooHoo, S. L., Sullivan, C. W. (1987). Spectral light absorption and quantum yield of photosynthesis in sea ice microalgae and a bloom of Phaeocystis from McMurdo Sound, Antarctica. Mar Ecol. Prog. Ser. 39: 175-189

Subba Rao, D. V., Platt, T (1984). Primary production of arctic waters. Polar Biol. 3: 191-201

Sullivan, C. W., Palmisano, A. C., Kottmeier, S. T., Grossi, S. M., Moe, R. (1985). The influence of light on growth and development of the sea-ice microbial community of McMurdo Sound. In: Siegfried, W. R., Condy, P. R., Laws, R. M. (eds.) Antarctic nutrient cycles and food webs. Springer-Verlag, Heidelberg, p. 78-83

Sverdrup, H. U. (1953). On conditions for the vernal blooming of phytoplankton. J. Cons. Explor. Mer 18: 287-295

Thomas, C. W. (1963). On the transfer of visible radiation through sea ice and snow. J. Glaciol. 4: 481-484

Warren, S. G. (1982). Optical properties of snow. Rev. Geophys. Space Phys. 20: 67-89

Welch, H. A., Bergmann, M. A., Jorgenson, J. K., Burton, W (1988). A subice suction corer for sampling epontic ice algae Can J. Fish. Aquat. Sci. 45: 562-568

Welch, H. E., Legault, J. A., Bergmann, M. A. (1987). Effects of snow and ice an the annual cycles of heat and light in Saqvaqjuac Lakes. Can. J. Fish. Aquat. Sci. 44: 1451-1461

Wofsy, S. C. (1983). A simple model to predict extinction coefficients and phytoplankton biomass in eutrophic waters. Limnol. Oceanogr. 28: 1144-1155 